\title{
The Impact of Experiential Marketing and Customer Satisfaction on Customer Commitment in the World of Social Networks
}

\author{
Khaled Alkilani ${ }^{1}$, Kwek Choon Ling ${ }^{1} \&$ Anas Ahmad Abzakh ${ }^{1}$ \\ ${ }^{1}$ Faculty of Business and Information Technology, UCSI University, Kuala Lumpur, Malaysia \\ Correspondence: Kwek Choon Ling, Faculty of Business and Information Technology, UCSI University, No.1, \\ Jalan Menara Gading, UCSI Heights, 56000 Kuala Lumpur, Malaysia. Tel: 60-16-688-6248. E-mail: \\ kwekcl@ucsi.edu.my
}

Received: September 16, 2012 Accepted: October 2, 2012 Online Published: December 31, 2012

doi:10.5539/ass.v9n1p262

URL: http://dx.doi.org/10.5539/ass.v9n1p262

\begin{abstract}
The objective of this research is to evaluate the inter-relationships among the experiential marketing, customer satisfaction and customer commitment in the context of the social networks users in Malaysia. A total of six hypotheses will be tested. A descriptive research will be carried out to address the research objective. Judgemental sampling technique and the distribution of a total 350 sets of questionnaire in the form of self-administered survey among the social networks users will be selected as part of the research methodology. The statistical data will be analyzed by SPSS software version 20. Both simple and multiple regression analyses will be used to verify the six proposed hypotheses. The findings concluded that only sense and feel experiences are positively related to the customer satisfaction as well as customer satisfaction is positively related to the customer commitment.
\end{abstract}

Keywords: sense, feel, think, act, relate, experiential marketing, customer satisfaction, and customer commitment

\section{Introduction}

The revolution of internet technology has changed the way how people communicated. One of the electronic communication platforms is social networks. Social networks consists of hundreds of millions of individuals from around the world, which is based on connecting people to people, people to things, and social networks surfers can determine the things that interested them. They can create enormous of networks of human relations, and communicate with their friends through electronic multimedia communication, e-mail, share photos, data, texts, and links. Therefore, social networks is going to be one of the richest sources of data on individuals and communities, creating an enormous amount of information about people, their interests, methods of interaction, and models of behaviour, which is continuously renewing data from time to time (McKinsey, 2011). The most common social networks are Facebook, MySpace, Twitter and Linkedln. Table 1 illustrates the statistical data in related to the social networking in Asian Countries.

Table1. Social networking in Asian countries

\begin{tabular}{cccc}
\hline Country & \% Reach of Social Networking & Average Minutes Per Visitor & Average Visits Per Visitor \\
\hline Singapore & 74.3 & 175.6 & 19.1 \\
South Korea & 68.0 & 277.8 & 15.1 \\
Malaysia & $\mathbf{6 6 . 6}$ & 181.2 & 14.2 \\
Hong Kong & 62.8 & 127.7 & 13.7 \\
India & 60.3 & 110.4 & 10.4 \\
Japan & 50.9 & 72.8 & 9.9
\end{tabular}

Source: comScore World Metric, December 2008

Source: Adopted from Lim (2009)

Due to the potential economic power of social networks, more and more corporations have used social networks 
(such as Facebook 'fan' page) as an effective tool to virally market their products through 'buzz' campaigns. In some cases, companies are finding that their own customers are taking the initiative to start Facebook "fan" page. Due to the important of social networks in supporting the corporation's marketing campaign, it has become important to understand the degree of customer commitment (ie., fan commitment) toward the social networks and how the experiential marketing and customer satisfaction affect the customer commitment.

\section{Literature Review}

\subsection{Customer Commitment}

Morgan and Hunt (1994) refer commitment as a lasting want of upholding certain relationship. Gruen (1995) defines commitment as a long-term orientation and desire of a buyer to have a long-term relationship with a seller. Thus, Garbarino and Johnson (1999) describe customer commitment as an important component of a successful relationship because it gives rise to mediate behaviours and it will help to build a long-term relationship between the service parties. Commitment within the customer-supplier relationships in the field of marketing has largely borrowed the concept of commitment developed from the context of relationship between employees and their organization (Mowday, Steers and Porter, 1979; Meyer and Alen, 1991). Zins (2001) has classified the customer commitment into three different conceptualizations: affective, calculative or continuance, and normative commitment. Each types of customer commitment conceptualization has different antecedents, contents and consequences (Zins, 2001). Fullerton (2003) defines the affective commitment as a consumer's sense of belonging and involvement with a service provider akin to emotional bonding. Affective commitment was adopted in view of its larger effect on loyalty in comparing to satisfaction (Johnson et al., 2001).

\subsection{Customer Satisfaction}

Westbrook and Reilly (1983) describe customer satisfaction as an emotional response to the experiences provided by and associated with particular products or services purchased, retail outlets, or even molar patterns of behaviour such as shopping and buyer behaviour, as well as the overall marketplace. From the perspective of 'implied after purchase and use', Churchill and Surprenant (1982) elaborate customer satisfaction as the outcome of purchase and use resulting from the buyer's comparison of the rewards and costs of the purchase relative to the anticipated consequences. In short, customer satisfaction is a conscious evaluation or cognitive judgment that the product has performed relatively well or poor, and suitable or unsuitable for its use/purpose. The extant literature has concluded that there is a positive relationship between customer satisfaction and customer commitment (Thorsten Hennig-Thurau, 2004; Morgan and Hunt, 1994; Larry and Hazer, 1986).

\subsection{Experiential Marketing}

Holbrook and Hirschman (1982) refer consumer experience as the consumer inputs and outputs associated with the experience. The marketing experience is referred to the market-based offering that is specifically created and staged for the consumers (Marconi, 2005). The psychology literature on experience argues that all experiences are comprised of three components: the experiential subject, the experiential object, and the experiential process (Russon, 2003). The experiential subject is the person who is doing the experiencing and in whom the experiential effect resides (such as the consumer). The experiential object is that what is experienced (such as the market offering). The experiential process is the act of experiencing the object by the subject. It is argued that the subject can experience the object in a variety of ways, including sensorially, emotionally, intellectually, imaginatively, physically, socially, and spiritually (Barrett, Mesquita, Ochsner and Cross, 2007).

Schmitt (1999) proposes the concept of strategic experiential modules (SEMs) that aims to help the managers to create different types of customer experiences for their customers. The experiential modules to be managed in the experiential marketing include sensory experiences (SENSE); affective experiences (FEEL); creative cognitive experiences (THINK); physical experiences, behaviours and lifestyles (ACT) and social-identity experiences that result from relating to a reference group or culture (RELATE). The purpose of experiential marketing is to create holistically integrated experiences that possess, at the same time, SENSE, FEEL, THINK, ACT and RELATE qualities. The studies in the extant literature have concluded that experiential marketing can be related to the customer satisfaction (Lee, Hsiao and Yang, 2010). The following contents will study these five dimensions of experiential marketing in detail.

\subsubsection{Sense Experience}

Schmitt (1999) argues that the SENSE marketing can be used as appeals to the senses with the objective of creating sensory experiences, through sight, sound, touch, taste and smell. SENSE marketing may be used to differentiate companies and products, to motivate customers and to add value to products through aesthetics or excitement. Vargo and Lusch (2004) assert that consumers' sensory experience enables consumer to develop 
experience logic for the purpose of forming his or her value judgements that attach to the goods and services offered. These attached value judgements consist of behavioural, emotional, cognitive, relational, and symbolic values (Vargo and Lusch, 2004). In other words, the experience logic allows consumer to merge emotional and rational elements inside the brain to assist himself or herself in forming the sensory experience towards a brand.

\subsubsection{Feel Experience}

Yang and He (2011) assert that the emotional experience includes moods and feelings with the purpose of creating effective experience that range from a little positive moods attached to a brand to strong emotions of joy and satisfaction. Feelings are most powerful when they occur during consumption. Strong feelings result from the contacts and interactions, and they develop over time. Accompanied by positive feelings in the consumption situation, a consumer embraces a positive emotion (Schmitt, 1999). Therefore, O'Shaughnessy and O'Shaughnessy (2003) mention that feel experience shows the "true self" of the individual by revealing what he or she considers being particularly significant. Mattila (2001) notes that "emotionally (feel) bonded customers tend to invest more in their relationships than customers lacking affective commitment".

\subsubsection{Think Experience}

According to Schmitt (1999), think experience is a creative and theoretical practice, which requires intelligence practices in order to create cognitive experience and problem solving through creative involvement with consumers. The aim of think experience is to encourage consumers to think and be attracted in a creative way so that it may produce re-evaluation feedback to the company and its brand. Schmitt (1999) concludes that think marketing appeals to target customers' convergent and divergent thinking through surprise, intrigue and provocation and the think experience will be expressed by delivering inspirations, high technology, and essence of surprises.

\subsubsection{Act Experience}

Schmitt (1999) addresses that act experience promotes customers' lives by targeting their physical experiences, showing them alternative ways of doing things, alternative lifestyles and interactions. The experience of action is designed to create experiences that concern consumer's physical body, behaviour, and lifestyle, as well as the experiences as the results of social interaction with other people. The experience of action leaves the consumers with sensation, influence and relationship (Schmitt, 1999). The purpose of the act experience is to improve the physical experience, to give impression upon behaviour pattern and lifestyle, as well as to enrich social interaction pattern of the strategy being implemented. Meanwhile, the experience of connection aims to relate the consumers with their culture and social-environment where the consumers live (Schmitt, 1999).

\subsubsection{Relate Experience}

According to Chang et al. (2011), relate experience based on individual's connection, social communities (such as gender, occupation, ethnicity, and lifestyle), social entities (such as nation and culture) through purchasing and the use of particular products or services, and their acquisition of social recognition and a sense of belonging. Schmitt (1999) claims that relate experience is performed through relating the individual to something outside his/her private state. Relate campaigns appeal to the individual's desire for self-improvement, appeal to the need to be perceived positively by individual others, and relate the person to a broader social system.

\subsection{Proposed Conceptual Framework}

Based on the study from Tsaur, Chiu and Wang (2008), their findings conclude that the relationship between the experiential marketing (sense, feel, think, act, and relate) and customer satisfaction could be formed as an indirect relationship. Oppositely, the research from Lee, Hsiao and Yang (2010) has pointed that experiential marketing generally has a direct relationship with customer satisfaction. However, the tested 'experiential marketing' construct in the study of Lee, Hsiao and Yang (2010) only encompasses sensation experience and association experience. In due respect, this is a controversy in the finding to ascertain the relationship between the experiential marketing and customer satisfaction as well as the absent of literature in testing the relationship between the five dimensions of experiential marketing and customer satisfaction in the context of social networks in Malaysia.

This research seeks to expand the influence of experiential marketing (ie., sense, feel, think, act and relate) towards the customer satisfaction as well as the impact of customer satisfaction on customer commitment, especially in the context of social networks in Malaysia. The research findings from this study will enable to close the research gap as mentioned above as well as provide clues how to increase the percentage reach of social networking and the average numbers of visits per visitor in the social networks in Malaysia. By understanding these clues, it will help the corporations to use the social networks as platforms to enhance their 
customers' commitment effectively and efficiently.

The conceptual framework for this research was developed based on the combination of models and constructs derived from the extant literature. Figure 1 illustrates the proposed conceptual framework which is developed for this research.

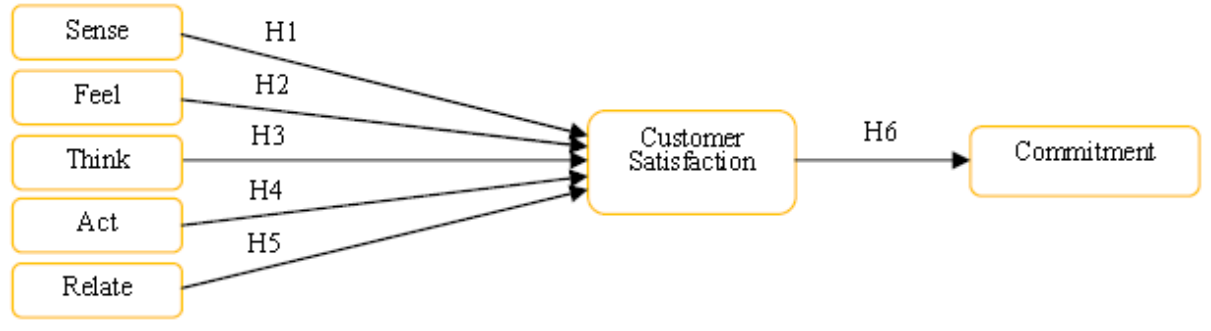

Figure 1. Propose conceptual framework

Prior discussion has led to a brief examination of the existing literature review and the development of the following hypotheses. The six tested hypotheses are:

H1: Sense experience is positively related to the customer satisfaction

$\mathrm{H} 2$ : Feel experience is positively related to the customer satisfaction

H3: Think experience is positively related to the customer satisfaction

H4: Act experience is positively related to the customer satisfaction

H5: Relate experience is positively related to the customer satisfaction

H6: Customer satisfaction is positively related to the customer commitment

\section{Research Methodology}

Positivism approach is adopted because this approach allows the researcher to search for truths of the observation by empirical evidence via the hypothetico-deductive method (Jankowicz, 2005). Primary data will be collected through self-administered survey based on the cross-sectional study.

\subsection{Questionnaire Design}

The adopted questionnaire can be divided into two parts. Part A will illustrate the respondents' demographic profiles and Part B will elaborate all the variables that used to measure various tested constructs. Table 2 provides the details of the operation definitions for the constructs that tested in the questionnaire.

Table 2. Operation definitions of the constructs

\begin{tabular}{|c|c|c|c|c|}
\hline Variables & $\begin{array}{l}\text { Number of } \\
\text { Items }\end{array}$ & $\begin{array}{l}\text { Measurement } \\
\text { Scale }\end{array}$ & Five-point Likert Scale & Source \\
\hline Sense (IV) & 3 & Interval & $\begin{array}{l}\text { Strongly disagree to } \\
\text { Strongly agree }\end{array}$ & $\begin{array}{l}\text { Lin, Chang, Lin, Tseng } \\
\text { and Lan (2009) }\end{array}$ \\
\hline Feel (IV) & 4 & Interval & $\begin{array}{l}\text { Strongly disagree to } \\
\text { Strongly agree }\end{array}$ & $\begin{array}{l}\text { Lin, Chang, Lin, Tseng } \\
\text { and Lan (2009) }\end{array}$ \\
\hline Think (IV) & 3 & Interval & $\begin{array}{l}\text { Strongly disagree to } \\
\text { Strongly agree }\end{array}$ & $\begin{array}{l}\text { Nuruni Ika and Kustini } \\
\text { (2009) }\end{array}$ \\
\hline Act (IV) & 4 & Interval & $\begin{array}{l}\text { Strongly disagree to } \\
\text { Strongly agree }\end{array}$ & $\begin{array}{l}\text { Nuruni Ika and Kustini } \\
\qquad(2009)\end{array}$ \\
\hline Relate (IV) & 3 & Interval & $\begin{array}{l}\text { Strongly disagree to } \\
\text { Strongly agree }\end{array}$ & $\begin{array}{l}\text { Lin, Chang, Lin, Tseng } \\
\text { and Lan (2009) }\end{array}$ \\
\hline $\begin{array}{l}\text { Customer Satisfaction } \\
\text { (DV) }\end{array}$ & 5 & Interval & $\begin{array}{l}\text { Strongly disagree to } \\
\text { Strongly agree }\end{array}$ & $\begin{array}{c}\text { Anderson and Srinivasan } \\
(2003)\end{array}$ \\
\hline $\begin{array}{c}\text { Customer } \\
\text { Commitment (DV) }\end{array}$ & 3 & Interval & $\begin{array}{l}\text { Strongly disagree to } \\
\text { Strongly agree }\end{array}$ & $\begin{array}{c}\text { Gabarino and Johnson } \\
\text { (1999) }\end{array}$ \\
\hline
\end{tabular}

3.2 Sampling Design

All the users of the respective internet based social networks will be targeted as the potential respondents. 
Judgemental sampling technique will be adopted in the study. A pilot test will be performed prior the full scale of the survey being conducted. A total of 350 sets of questionnaire will be distributed via the self-administered survey among the users of the social networks. Descriptive analysis, scale measurement (both reliability and validity tests) and inferential analysis will be carried out in the data analysis.

\section{Research Results}

\subsection{Respondents' Demographic Profile}

Based on this survey, the male gender represented $53 \%$ of the total respondents and the rest of $47 \%$ of the respondents is represented by female gender. The major profiling of the respondents' age distribution from the survey were between the age group of 26-34 years old (45\%) and followed by the age group of 18-25 years old (39\%). In term of the nationality, $96.7 \%$ of the respondents are Malaysian and the rest of $3.3 \%$ of the respondents is non-Malaysian. According to the survey, the time spent online per week by the respondents was distributed as follow: 36-40 hours (27.3\%); 31-35 hours (23.6\%); 26-30 hours (12.4\%); 21-25 hours (11.3\%); 16-20 hours (6.5\%); 6-10 hours (2.9\%); $0-5$ hours (2.5\%); and more than 41 hours $(2.5 \%)$.

\subsection{Reliability Test}

The reliability of a measure shows the steadiness and consistency with which the tool measures the concept and assists to evaluate the goodness of a measure (Cavana et al., 2001). All of the variables were testified for the consistency reliability of the items within the variables by using Cronbach's alpha. In general, the value of Cronbach's alpha with range of more than 0.70 is considered acceptable and good (Cavana et al., 2001). This value was used as a guideline to evaluate the stability and consistency of the tested variables. Based on the research finding as indicated in Table 3, the values of Cronbach's alpha for all the tested constructs are more than the value of 0.7 , ranging from the lowest value of Cronbach's alpha (Think Experience $=0.731$ ) to the higher value of Cronbach's alpha (Customer Satisfaction $=0.894$ ).

\subsection{Validity Test}

Validity can be measured by examining through content, criterion and construct validity. Construct validity was adopted as a validity measurement and factor analysis was used to measure the construct validity (Cavana et al., 2001). According to the result of factor analysis in Table 3, the constructs were suitable for factor analysis due to the value of Kaiser-Meyer-Olkin (KMO) which was 0.881(between 0.5 and 1.0), and statistical test for Bartlett test of sphericity was significant $(\mathrm{p}=0.0001$; d.f. $=300$ ) for all the correlations within a correlation matrix (at least for some of the constructs). The principal component analysis and VARIMAX procedure in orthogonal rotation were adopted in the factor analysis, the result showed that Eigenvalues for all the constructs were greater than 1.0, ranging from the lowest of 1.101 (Commitment) to the highest of 8.480 (Sense experience).

Table 3. Six factors identified by the principal components factor analysis

\begin{tabular}{|c|c|c|c|c|c|c|}
\hline $\begin{array}{l}\text { Number } \\
\text { of } \\
\text { Factors }\end{array}$ & Factor's Name & Variable & $\begin{array}{l}\text { Factor } \\
\text { Loading }\end{array}$ & Eigen-value & $\begin{array}{l}\text { Percentage of } \\
\text { Variance } \\
\text { Explained }\end{array}$ & $\begin{array}{l}\text { Cronbach's } \\
\text { Reliability } \\
\text { Coefficients }\end{array}$ \\
\hline \multirow[t]{3}{*}{$\mathrm{F} 1$} & \multirow[t]{3}{*}{ Sense } & The website is appropriate & 0.761 & 8.480 & 3.768 & 0.789 \\
\hline & & The website is interesting. & 0.765 & & & \\
\hline & & The website lacks sensory & 0.702 & & & \\
\hline \multirow[t]{4}{*}{$\mathrm{F} 2$} & \multirow[t]{4}{*}{ Feel } & $\begin{array}{l}\text { I paid attention to the applications } \\
\text { in the website }\end{array}$ & 0.813 & 2.353 & 3.050 & 0.823 \\
\hline & & I feel the website is secure & 0.674 & & & \\
\hline & & $\begin{array}{l}\text { The design of the website made me } \\
\text { feel comfortable }\end{array}$ & 0.715 & & & \\
\hline & & $\begin{array}{l}\text { I feel safe in your transaction with } \\
\text { the website }\end{array}$ & 0.780 & & & \\
\hline \multirow[t]{3}{*}{ F3 } & \multirow[t]{3}{*}{ Think } & $\begin{array}{l}\text { The digital products or a service } \\
\text { provided by the website tries to } \\
\text { intrigue me }\end{array}$ & 0.763 & 1.928 & 2.805 & 0.731 \\
\hline & & $\begin{array}{l}\text { The website stimulates my } \\
\text { curiosity }\end{array}$ & 0.647 & & & \\
\hline & & $\begin{array}{l}\text { The digital products or a service } \\
\text { provided by the website tries to } \\
\text { appeal to my creative thinking }\end{array}$ & 0.750 & & & \\
\hline
\end{tabular}




\begin{tabular}{|c|c|c|c|c|c|c|}
\hline \multirow[b]{2}{*}{ F4 } & \multirow[b]{2}{*}{ Act } & \multirow{3}{*}{$\begin{array}{l}\text { Willing to share and interact social } \\
\text { transactions experience in the } \\
\text { website with friends } \\
\text { Activities and applications } \\
\text { provided by a website attract me to } \\
\text { join }\end{array}$} & \multirow{2}{*}{0.704} & \multirow{3}{*}{1.479} & \multirow{3}{*}{2.115} & \multirow{3}{*}{0.852} \\
\hline & & & & & & \\
\hline & & & 0.821 & & & \\
\hline & & $\begin{array}{l}\text { I would like to further explore this } \\
\text { website's other activities }\end{array}$ & 0.862 & & & \\
\hline & & $\begin{array}{l}\text { Using such website will improve } \\
\text { my social life with friends }\end{array}$ & 0.820 & & & \\
\hline \multirow[t]{3}{*}{ F5 } & Relate & $\begin{array}{l}\text { Creating a profile in social network } \\
\text { represents my enthusiasm toward } \\
\text { that website activity }\end{array}$ & 0.789 & 1.465 & 2.102 & 0.761 \\
\hline & & $\begin{array}{l}\text { Having profile in social network } \\
\text { enables me to exchange } \\
\text { experiences with those who have } \\
\text { common interest as mine. }\end{array}$ & 0.863 & & & \\
\hline & & $\begin{array}{l}\text { Social network experience brings } \\
\text { family and friends closer together }\end{array}$ & 0.696 & & & \\
\hline \multirow[t]{7}{*}{ F6 } & $\begin{array}{l}\text { Customer } \\
\text { satisfaction }\end{array}$ & $\begin{array}{l}\text { I am satisfied with my decision to } \\
\text { use this social network }\end{array}$ & 0.876 & 1.142 & 2.062 & 0.894 \\
\hline & & $\begin{array}{l}\text { My choice to use this social } \\
\text { network was a wise one }\end{array}$ & 0.734 & & & \\
\hline & & $\begin{array}{l}\text { I feel badly regarding my decision } \\
\text { to use this social network }\end{array}$ & 0.661 & & & \\
\hline & & $\begin{array}{l}\text { I think I did the right thing by using } \\
\text { this social network }\end{array}$ & 0.698 & & & \\
\hline & & $\begin{array}{l}\text { I am happy that I use this social } \\
\text { network }\end{array}$ & 0.818 & & & \\
\hline & & $\begin{array}{l}\text { I feel committed to social network } \\
\text { that I use }\end{array}$ & 0.822 & & & \\
\hline & & $\begin{array}{l}\text { I am proud to belong to this social } \\
\text { network }\end{array}$ & 0.638 & & & \\
\hline F7 & Commitment & $\begin{array}{l}\text { If a social network that I use were } \\
\text { no longer to exist, this would be a } \\
\text { significant loss for me }\end{array}$ & 0.589 & 1.101 & 2.046 & 0.764 \\
\hline
\end{tabular}

\section{Note:}

KMO Measure of Sampling Adequacy $=0.881 ; \mathrm{p}=0.0001(\mathrm{p}<0.05) ; \mathrm{df}=300$

Cumulative Percentage Rotation Sums of Squared Loadings $=71.790$

The factor loadings for all items within the constructs were more than 0.50 , therefore discriminant validity indicated that all items were allocated according to the different constructs. Hence, the items supported respective constructs.

\subsection{Multiple Regression Analysis}

Multiple regression analysis was carried out to test the five hypotheses (H1, H2, H3, H4, and H5). The result of the multiple regression analysis is presented in Table 4. 
Table 4. Results of multiple regression analysis

\begin{tabular}{|c|c|c|c|c|c|c|c|c|}
\hline & & \multicolumn{2}{|c|}{$\begin{array}{c}\text { Unstandardized } \\
\text { Coefficients }\end{array}$} & \multirow{2}{*}{$\begin{array}{c}\begin{array}{c}\text { Standardized } \\
\text { Coefficients }\end{array} \\
\text { Beta }\end{array}$} & \multirow{2}{*}{$\mathrm{T}$} & \multirow{2}{*}{ Sig. } & \multicolumn{2}{|c|}{ Collinearity Statistics } \\
\hline & & B & Std. Error & & & & Tolerance & VIF \\
\hline \multirow[t]{6}{*}{1} & (Constant) & 3.738 & 1.000 & & 3.740 & 0.000 & & \\
\hline & Sense & 0.248 & 0.070 & 0.182 & 3.530 & 0.000 & 0.615 & 1.626 \\
\hline & Feel & 0.671 & 0.068 & 0.555 & 9.893 & 0.000 & 0.518 & 1.931 \\
\hline & Think & 0.126 & 0.075 & 0.084 & 1.676 & 0.095 & 0.651 & 1.537 \\
\hline & Act & -0.005 & 0.043 & -0.005 & -0.106 & 0.915 & 0.811 & 1.234 \\
\hline & Relate & 0.078 & 0.078 & 0.047 & 0.999 & 0.319 & 0.729 & 1.372 \\
\hline
\end{tabular}

Notes:

Dependent variable: Customer satisfaction.

Independent variable: five factors of experiential marketing representing the determinants of customer satisfaction

$R=74.9$ percent; $R$ Square $=56.1$ percent; Adjusted $R$ Square $=55.3$ percent; $F=68.854 ; P=0.000(p<0.05)$

Based on findings from the Table 4, the $\mathrm{p}$ value of the $\mathrm{t}$-test $(\mathrm{p}=0.000)$ is less than the alpha value of 0.05 in $\mathrm{H} 1$ and $\mathrm{H} 2$, therefore, $\mathrm{H} 1$ and $\mathrm{H} 2$ are supported. In conclusion, the sense and feel experiences are positively related to the customer satisfaction. Meanwhile, the p values for the other hypotheses $(\mathrm{H} 3, \mathrm{H} 4$, and H5) are more than the alpha value of 0.05 . Therefore, it may be concluded that think, act, and relate experiences are not significantly related to the customer satisfaction. The Tolerance Value was ranged between $0.615-0.811$ in which were all more than 0.10 and the VIF value ranges from 1.234-1.931 in which are all less than 5 (Hair et al., 2006). Therefore, the problem of multicollinearity does not exist. The change of the customer satisfaction is explained 56.1 percent $(\mathrm{R}$ Square $=0.561)$ by a combination of various independent variables, including sense and feel experiences. Based on the Table 4, the multiple regression equation was formed as following: Customer satisfaction $=3.738+0.248($ Sense $)+0.671($ Feel $)$.

\subsection{Simple Regression Analysis}

Simple regression analysis was carried out to test the sixth hypothesis (H6). The result of the simple regression analysis is presented in Table 5 .

Table 5. Result of simple linear regression analysis

\begin{tabular}{|c|c|c|c|c|c|c|c|c|}
\hline & & \multicolumn{2}{|c|}{$\begin{array}{l}\text { Unstandardized } \\
\text { Coefficients }\end{array}$} & \multirow{2}{*}{$\begin{array}{c}\text { Standardized } \\
\text { Coefficients }\end{array}$} & \multirow{2}{*}{$\mathrm{T}$} & \multirow[b]{2}{*}{ Sig. } & \multicolumn{2}{|c|}{$\begin{array}{l}\text { Collinearity } \\
\text { Statistics }\end{array}$} \\
\hline & & B & Std. Error & & & & Tolerance & VIF \\
\hline \multirow[t]{2}{*}{1} & (Constant) & 3.857 & 0.679 & & 5.678 & 0.000 & & \\
\hline & Customer satisfaction & 0.377 & 0.034 & 0.558 & 11.079 & 0.000 & 1.000 & 1.000 \\
\hline
\end{tabular}

Notes:

Dependent variable: Commitment

Independent variable: Customer satisfaction

$\mathrm{R}=55.8$ percent; $\mathrm{R}$ Square $=31.1$ percent; Adjusted $\mathrm{R}$ Square $=30.8$ percent; $\mathrm{F}=123.135 ; \mathrm{P}=0.000(\mathrm{p}<0.05)$

According to Table 5, the Tolerance Value was 1 (more than 0.10) and the VIF value was 1 (less than 5) (Hair et al., 2006). The findings showed that there is no multicollinearity problem in the study. The result of simple regression analysis is presented in Table 5 , the $p$ value of the $t$-test $(p=0.000)$ between customer satisfaction and commitment is less than the alpha value of 0.05 and the unstandardized beta coefficient is 0.377 . Therefore, there is a positive relationship between customer satisfaction and commitment. The study also concluded that the change of commitment is explained 31.1 percent $(\mathrm{R}$ square $=31.1$ percent $)$ by the customer satisfaction. The simple regression equation was formed as following: Commitment $=3.857+0.377$ (Customer satisfaction). 


\section{Conclusion}

\subsection{Conclusion of Hypotheses}

As a result of this research, sense and feel experiences are positively related to customer satisfaction, as well as customer satisfaction is positively related to commitment. On the other hand, the findings from this research rejects think, act, and relate experiences to be related with customer satisfaction.

\subsection{Implications of Research Findings}

The research findings do provide some insights and feedback for the social networks in terms of marketing strategy. Social networks providers should emphasize the degree of sense and feel experiences among the users of the social networks for the purpose of enhancing their satisfaction level. The administrators should adopt an integrated approach to develop determinants in evaluating the customer experience. By enhancing customer satisfaction, this will lead to a higher degree of customer commitment among the users towards the social networks.

\subsection{Limitations of the Research}

The study is based on cross-sectional data. Due to the inherent limitation of cross-sectional study, the research findings are not able to "explain why the observed patterns are there" (Easterby-Smith, Thorpe and Lowe, 2003). In other words, the current findings indicate that the think, act, and relate do not have significant relationship with customer satisfaction in context of social networks in Malaysia, the observed dependence effect may no longer be valid in the long run. In addition, the adoption of judgemental sampling technique has reduced the generalization of the research finding.

\subsection{Recommendations for Further Research}

Due to the limitations of this research, a few recommendations are suggested for further research such as the adoption of longitudinal study and probability sampling technique.

\section{References}

Anderson, R. E., \& Srinivasan, S. S. (2003). E-satisfaction and E-loyalty: A contingency framework. Psychology \& Marketing, 20(2), 123-138. http://dx.doi.org/10.1002/mar.10063

Barrett, L. F., Mesquita, B., Ochsner, K. N., \& Cross, J. J. (2007). The experience of emotion. Annual Review of Psychology, 58, 373-403. http://dx.doi.org/10.1146/annurev.psych.58.110405.085709

Chang, H. J., Huang, C. W., \& Lien, C. Y. (2012). Relationship models of experience satisfaction in residential refurbishment. African Journal of Business Management, 6(28), 8446-8458.

Churchill, G. A. Jr., \& Surprenant, C. (1982). An investigation into the determinants of customer satisfaction. Journal of Marketing Research, 19(4), 491-504. http://dx.doi.org/10.2307/3151722

Easterby-Smith, M., Thorpe, R., \& Lowe, A. (2003). Management research: An introduction (2nd ed.). California: SAGE Publication.

Fullerton, G. (2005). How commitment both enables and undermines marketing relationship. European Journal of Marketing, 1372-1388. http://dx.doi.org/10.1108/03090560510623307

Garbarino, E., \& Johnson, M. S. (1999). The different roles of satisfaction, trust, and commitment in customer relationship. Journal of Marketing, 63, 70-87. http://dx.doi.org/10.2307/1251946

Gruen, T. W. (1995). The outcome set of relationship marketing in consumer markets. International Business Review, 59(4), 449-456.

Hair, J. F. J., Black, W. C., Babin, B. J., Anderson, R. E., \& Tatham, R. L. (2006). Multivariate data analysis. New Jersey: Pearson Education.

Holbrook, M. B., \& Hirschman, E. C. (1982). The experiential aspects of consumption: Consumer fantasies, feeling and fun. Journal of Consumer Research, 9(2), 132-140. http://dx.doi.org/10.1086/208906

Jankowicz, A. D. (2005). Business research project (4th ed.). Thomson Learning: London.

Johnson, M., Gufstafsson, A., Andreassen, T. W., Lervik, L., \& Cha, J. (2001). The evolution and future of national customer satisfaction index models. Journal of Economic Psychology. Retrieving from http://www.redaksjonen.com/Artikler/82KTIifremtiden.pdf http://dx.doi.org/10.1016/S0167-4870(01)00030-7

Larry, W., \& Hazer, J. T. (1986). Antecedents and consequences of satisfaction and commitment in turnover 
models: A reanalysis using latent variable structural equation methods. Journal of Applied Psychology, 71(2), 219-231. http://dx.doi.org/10.1037/0021-9010.71.2.219

Lee, M. S., Hsiao, H. D., \& Yang, M. F. (2011). The study of the relationships among experiential marketing, service quality, customer satisfaction and customer loyalty. The International Journal of Organizational Innovation, 3(2), 353-379.

Lim, Y. H. (2009). Snapshot of social networking in Malaysia. Grey Review: The Social Web Journal. Retrieving from http://www.greyreview.com/2009/07/28/snapshot-of-social-networking-in-Malaysia

Lin, K. M., Chang, C. M., Lin, Z. P., Tseng, M. L., \& Lan, L. W. (2009). Application of experiential marketing strategy to identify factors affecting guests' leisure behavior in Taiwan Hot-Spring Hotel. WSEAS Transaction on Business and Economics, 6(5), 229-240.

Malhota, N., \& Peterson, M. (2006). Basic marketing research: A decision-making approach (2nd ed.). New Jersey: Prentice Hall.

Marconi, J. (2005). Creating the Marketing Experience: New Strategies for Building Relationships with Your Target Market. USA: Thomson Learning.

Mattila, A. S. (2001). Emotional bonding and restaurant loyalty. Cornell Hotel and Restaurant Administrative Quarterly, 42(6), 73-79. http://dx.doi.org/10.1016/S0010-8804(01)81012-0

McKinsey. (2011). Big Data: The Next Frontier for Innovation, Competition, and Productivity. McKinsey Global Institute.

Meyer, J. P., \& Allen, N. J. (1991). A Tree-component conceptualization of commitment. Human Resource Management Review, 1, 61-89. http://dx.doi.org/10.1016/1053-4822(91)90011-Z

Morgan, R. M., \& Hunt, S. (1994). The commitment-trust theory of relationship marketing. Journal of Marketing, 58(3), 20-38. http://dx.doi.org/10.2307/1252308

Mowday, R., Steers, R., \& Porter, L. (1979). The measurement of organizational commitment. Journal of Vocational Behavior, 14, 224-247. http://dx.doi.org/10.1016/0001-8791(79)90072-1

Nuruni Ika, \& Kustini. (2011). Experiential marketing, emotional branding, and brand trust and their effect on loyalty on Honda Motorcycle product. Journal of Economics, Business and Accountancy Ventura, 14(1), 19-28.

O’Shaughnessy, J. A., \& O’Shaughnessy, N. J. (2003). The Marketing Power of Emotion. Oxford: Oxford University Press.

Russon, J. (2003). Human Experience: Philosophy, Neurosis, and the Elements of Everyday Life. New York: State University of New York.

Schmitt, B. (1999). Experiential Marketing: How to Get Customers to Sense, Feel, Think, Act, Relate to Your Company and Brands. New York: The Free Press.

Thorsten Henning - Thurau. (2004). Customer orientation of service employees: Its impact on customer satisfaction, commitment, and retention. International Journal of Service Industry Management, 15(5), 460-478. http://dx.doi.org/10.1108/09564230410564939

Tsau, S. H., Chiu, Y. T., \& Wong, C. H. (2007). The visitors behavioral consequences of experiential marketing. Journal of Travel \& Tourism Marketing, 21(1), 47-64. http://dx.doi.org/10.1300/J073v21n01_04

Vargo, S. L., \& Lusch, R. F. (2004). Evaluating to a new dominant logic for marketing. Journal of Marketing, 68(1), 1-17. http://dx.doi.org/10.1509/jmkg.68.1.1.24036

Westbrook, R. A., \& Reilly, M. D. (1983). Value-percept disparity: An alternative to the disconfirmation of expectations theory of consumer satisfaction. Advances in Consumer Research, 10, 256-261.

Yang, Z. Y., \& He, L. Y. (2011). Goal, customer experience and purchase intention in a retail context in China: An empirical study. African Journal of Business Management, 5(16), 6738-6746.

Zins, A. H. (2001). Relative attitudes and commitment in customer loyalty models: Some experiences in the commercial airline industry. International Journal of Service Industry Management, 12(3), $269-294$. http://dx.doi.org/10.1108/EUM0000000005521 